УДК [597.2/5:577.17]:504.05

DOI https://doi.org/10.26661/2410-0943-2020-1-02

\title{
Вміст кортизолу та тиреоїдних гормонів у плазмі крові карася китайського Carassius auratus (Linnaeus, 1758) за умов амонійного навантаження
}

\author{
Причепа М. В., Коваленко Ю. О., Потрохов О. С., Худіяш Ю. М. \\ ORCID: 0000-0002-3114-2402, \\ Інститут гідробіології Національної академії наук України, Україна \\ prichepa1987@ukr.net
}

Ключові слова: карась китайський, гормони, вплив амонію, адаптивні реакиії.
Розглянуто особливості зміни вмісту кортизолу, тироксину та трийодтироніну в плазмі крові карася китайського до довготривалого перебування у середовищі, забрудненому сполуками амонію. Вміст гормонів було визначено імуноферментним методом із використанням стандартних комерційних наборів. Встановлено, що у плазмі крові карася 3 водойми, яка містить високу концентрацію амонійного азоту в воді (до 48,0 мг N/дм3), рівень трийодтироніну підвищувався у 1,38 раза, проте вміст тироксину знижувався у 3,87 раза порівняно з умовним контролем. Зміна показників вмісту тиреоїдних гормонів у сироватці крові карася свідчить на користь трансформації резервів Т4 у активну форму Т3. Це наголошує на активації обмінних процесів за впливу сполук амонію. Також були встановлені корелятивні зв'язки між зростанням вмісту неорганічного амонію та T3 (r=0,847) і зниженням T4 (r=-0,773). Також встановлено ( $\geq 00,05)$ нижчий вміст кортизолу у плазмі крові карася, що перебував у водоймі, забрудненій сполуками неорганічного амонію. Це свідчить на користь відсутності явищ гострого стресу на момент проведення досліджень.

Зміна вмісту Т3 вказує на спрямованість гормональної відповіді риб на вплив надмірних концентрацій неорганічного амонію. У результаті тривалого пристосування риб до токсичного забруднення водного середовища у плазмі крові карася китайського істотно змінюється вміст гормонів, які залучені у регуляції обміну речовин, зокрема на посилення процесів, спрямованих на забезпечення нормальної життєдіяльності. У результаті цього нами встановлено також суттєві відмінності між лінійномасовими показниками риб, що було наслідком тривалого перебування угруповання карася китайського у не типових екологічних для цього виду умовах. Отримані результати зміни вмісту гормонів: кортизолу, тироксину, трийодтироніну відображають фізіологічний стан досліджуваного виду риб за умов антропогенного забруднення. Це дозволяє їх активно залучати для проведення біомоніторингу екологічного стану окремих водойм, зокрема за інтенсивного забруднення середовища сполуками азоту. Отримані результати доповнюють вже наявні показники щодо дослідження фізіолого-біохімічних показників карася китайського за умов азотного навантаження. 


\title{
The content of cortisol and thyroid hormones in the blood plasma of Goldfish Carassius auratus (Linnaeus, 1758) under ammonium loading
}

\author{
Prychepa M. V., Kovalenko Yu. O., Potrokhov A. S., Khydiyash Yu. M. \\ Institute of Hydrobiology of National Academy of Science of Ukraine, Ukraine
}

Key words: goldfish, hormones, influence of ammonium, adaptive reactions.
The peculiarities of changes in the content of cortisol, thyroxine and triiodothyronine in the blood plasma of goldfish for a long stay in an environment contaminated with ammonium compounds are considered. The hormone content was determined by the enzyme immunoassay using standard commercial kits. It was found that in the blood plasma of goldfish from the reservoir, which contains a high concentration of ammonium nitrogen in water (up to $48.0 \mathrm{mg} \mathrm{N} / \mathrm{dm} 3$ ), the level of triiodothyronine increased by 1.38 times, however, the thyroxine content decreased by 3.87 times compared to the conditional control. The change in the parameters of the content of thyroid hormones in the goldfish in the blood plasma testifies in favor of the transformation of T4 reserves into the active form of T3. This emphasizes the activation of metabolic processes when exposed to ammonium compounds. Also, correlations were established between an increase in the content of inorganic ammonium and $\mathrm{T} 3(\mathrm{r}=0.847)$ and a decrease in $\mathrm{T} 4(\mathrm{r}=-0.773)$. It was also found $(\mathrm{p} \geq 0.05)$ a low content of cortisol in the blood plasma of a goldfish that was in a reservoir contaminated with inorganic ammonium compounds. This indicates the absence of acute stress phenomena at the time of the research.

The change in the content of $\mathrm{T} 3$ indicates the direction of the hormonal responses of fish to the effect of excessive concentrations of inorganic ammonium. As a result of long-term adaptation of fish to toxic pollution of the aquatic environment in the blood plasma of the goldfish, the content of hormones involved in the regulation of metabolism, in particular, the enhancement of processes aimed at ensuring normal vital activity, changes significantly. As a result, we also found significant differences between the linear mass indicators of fish, which was a consequence of the long stay of the goldfish group in non-typical ecological conditions for this species. The obtained results of changes in the content of hormones: cortisol, thyroxine, triiodothyronine reflect the physiological state of the studied fish species under conditions of anthropogenic pollution. This allows them to be actively involved in biomonitoring of the ecological state of individual water bodies, including for intensive pollution of the environment with nitrogen compounds. The results obtained supplement the already existing indicators for the study of physiological and biochemical parameters of goldfish under nitrogen loading.

\section{Вступ}

Розвиток сільського господарства та глобальні кліматичні зміни призводять до екзогенного та ендогенного надходження біогенних сполук до водойм. Будь-які хімічні сполуки антропогенного походження, що потрапляють до водного середовища в кількості, яка перевищує середні природні фонові значення, можуть розглядатись як забруднювачі. Особливо яскраво це виражено на озерних та ставкових екосистемах. Це істотно впливає на якість водного середовища, яке, своєю чергою, $\epsilon$ місцем існування для багатьох представників водної фауни. За таких умов можуть створюватись зони посиленого або екстремального забруднення. Це створює екологічні умови, які виходять за межі оптимальних для більшості представників іхтіофауни.

Вплив неорганічного азоту на риб висвітлено у літературі $\mathrm{i}^{1-3}$. Проте такі дослідження спрямовані на вирішення впливу високих концентрацій неорганічних сполук азоту на життєстійкість риб, функціонування окремих органів у короткочасових експериментах. У свою чергу, механізми пристосування риб до впливу сполук неорганічного азоту у разі довготривалого перебування у такому середовищі залишаються маловивченими ${ }^{4}$. Тому для його визначення необхідно проводити комплексні дослідження, в тому числі і за біохімічними показниками водяних тварин, зокрема за вмістом гормонів у плазмі крові риб. 
Токсичні речовини можуть змінювати структуру та функції органів та тканин, зокрема ендокринних залоз риб, що може мати серйозні наслідки для процесів росту, розвитку та репродукції риб5 . Натепер дослідження впливу токсичних речовин антропогенного походження на гідробіонтів здебільшого проводяться в розрізі модельних експериментів. Такі дослідження зазвичай виявляють чутливість тією чи іншою мірою гідробіонтів, але не здатні повністю розкрити адаптивні властивості їх до негативної дії факторів середовища. У природних водних екосистемах характер і тривалість дії негативних чинників істотно відрізняються, що зумовлює дещо інші особливості відповіді організму на різних рівнях адаптації 6 . Види, що існують за несприятливих екологічних умов, формують угруповання, які здатні забезпечувати такі стратегії виживання, які дозволяють їм існувати та відтворюватись за цих умов. Серед важливих показників фізіолого-біохімічного стану провідне місце належить вмісту гормонів, оскільки нейрогуморальна система залучена у регулювання адаптивної відповіді організму риб за тривалого пристосування. Вивчення особливостей зміни вмісту гормонів у плазмі крові риб можуть розкривати деякі аспекти, які пов'язані 3 адаптивними реакціями у разі існування в умовах надмірного токсичного забруднення. Відомо, що зміни вмісту гормонів у плазмі риб часто використовують як біомаркери щодо оцінки фізіологічного стану природних угруповань риб ${ }^{7-8}$. Завдяки своїй чутливості до коливання чинників довкілля зміна вмісту тиреоїдних гормонів та кортизолу яскраво ілюструють зміни фізіологічного стану риб ще до видимих ознак деградації водної екосистеми ${ }^{7}$. Саме водойми дендропарку Олександрії (Київська обл.) яскраво ілюструють проблему тривалого забруднення сполуками неорганічного азоту водного середовища. На зазначеній території низка водойм забруднюються вже близько 20 років шляхом надходження через підземні водні джерела значної кількості сполук неорганічного азоту. На це наголошують численні дослідження, проведені на цих водоймах $^{9-11}$. Саме на цих водоймах можна прослідкувати особливості поетапної адаптації риб до високих концентрацій неорганічного азоту.

Своєю чергою зміна вмісту гормонів, які залучені у регуляцію енергетичного обміну, може розкривати один з аспектів адаптивної стратегії риб за існування у нестабільному середовищі.

Мета дослідження - дослідити вміст ключових діагностично важливих гормонів у плазмі крові карася китайського Carassius auratus (L) за дії надмірної концентрації неорганічного азоту, що $\epsilon$ важливим у проведенні екологічного моніторингу водойм такого типу.

\section{Матеріали та методи}

Відбір біологічного матеріалу проводили протягом липня 2018 р. у водоймах м. Білої Церкви (ставки дендропарку «Олександрія»). Відлов риб здійснювали гачковими знаряддями лову. Об'єктом досліджень був карась китайський Carassius auratus (L). Вік риб - 3 роки. Відбір проб води для гідрохімічних досліджень здійснювали у ранкові години. Вміст розчиненого кисню визначали за методом Вінклера, концентрацію біогенних речовин (азоту нітратного, нітритного та амонійного) здійснювали фотоколориметричним методом 3 використанням приладу КФК - 2 МП ${ }^{12}$. Водневий показник $(\mathrm{pH})$ визначали за допомогою рН-метра РН-009 (1). Вміст гормонів у плазмі крові визначали після центрифугування крові протягом 15 хв. при 6 тис. об./хв. Вміст кортизолу, тироксину та трийодтироніну визначали імуноферментним методом 3 використанням наборів реагентів «ДС-ІФА-Стероїд-Кортизол» «Т3-ІФА» та «Т4-ІФА» (Науково-виробнича лабораторія «Гранум», Україна) за допомогою ІФА-аналізатopa Rayto RT-2100C. Статистичну обробку матеріалу проводили за допомогою програм Excel iз пакета Microsoft Office та Statistica 5.5. Експериментальні дані представлені як середнє арифметичне значення кількісних показників (M) \pm стандартна помилка середнього арифметичного (m). У таблицях і на рисунках наведені середні значення і помилки середнього арифметичного. Для встановлення суттєвості відмінностей між варіантами дослідів використовували метод парного порівняння варіант (критерій Стьюдента). Різниця вважалась статистично значущою за рівня ймовірності $\mathrm{P} \leq 0,05$. Під час виконання досліджень було враховано положення, узгоджені «Свропейською конвенцією про захист хребетних тварин, які використовуються для експериментів та інших цілей» (Страсбург, Франція, 1985) ${ }^{13}$.

У процесі досліджень нами було умовно поділені водойми на ті, які забруднюються сполуками азоту (водойма 2), i ті, що характеризувались референтними значеннями цих показників (водойма 1).

Ставок № 1 дендропарку «Олександрія». Штучно створена водойма каскадного типу, що розташована у м. Біла Церква. Водойма має площу 0,4 га, середня глибина становить 1,0 м, а максимальна - 2,5 м. Іхтіофауна складається 311 видів риб (власні дані). Дані стосовно гідрохімічних показників наведені у табл. 1.

Ставок № 2 дендропарку «Олександрія». Штучно створена водойма каскадного типу, має площу 1,0 га, середню глибину - 1,2 метра, максимальну - 3,5 метра. Іхтіофауна налічує 2 види чебачок амурський Pseudorasbora parva (Temmink 
and Schlengel, 1846) і карась китайський Carrasius auratus (Linnaeus, 1758). Дані стосовно гідрохімічних показників наведені у табл. 1.

\section{Результати}

За результатами проведених гідрохімічних досліджень нами було виявлено істотні відмінності між водоймами дендропарку «Олександрія», зокрема за вмістом біогенних сполук (табл. 1).

Згідно $з$ отриманими даними стосовно вмісту цих сполук у липні 2018 року їх концентрація була значно вищою у забрудненій водоймі (дендропарк «Олександрія»), ніж у чистій, що вплинуло на фізіологічний стан риб.

Згідно з табл. 2, у разі існування угруповань карася китайського протягом тривалого часу у водоймі зі значними концентраціями сполук амонію у риб відбуваються істотні зміни у темпах лінійно-масового росту, що можна розглядати як негативний наслідок дії зазначених сполук на організм карася.

Нами було проаналізовано зміни вмісту тиреоїдних гормонів карася, угруповання якого тривалий час (близько 20 років) перебували у водоймі, яка інтенсивно забруднюється сполуками азоту (рівень амонію сягав до 48,0 мгN/дм³ - 2018 р.).

За результатами наших досліджень у риб із забрудненої водойми № 2 було встановлено у 3,87 раза нижчий рівень Т4, ніж у контролі (рис. 1). На противагу цьому рівень Т3 (який синтезується переважно з Т4), порівняно 3 контролем, був вищий у 1,38 раза (рис. 2). Також були встановлені корелятивні зв'язки між зростанням вмісту неорганічного амонію та Т3 $(\mathrm{r}=0,847)$ і зниженням T4 $(\mathrm{r}=-0,773)$.

Рівень кортизолу у сиворотці крові карася із водойми, що забруднена амонійним азотом, був менший у 1,5 раза $(\mathrm{p} \leq 0,05)$, ніж у особин карася із чистої водойми (рис. 3 ).

\section{Обговорення}

Відомо, що до переліку найважливіших гідрохімічних характеристик якості води та стану водної екосистеми належать показники концентрації біогенних речовин ${ }^{3,14}$, а саме сполук азоту i фосфору, які є провідними чинниками у процесах евтрофування поверхневих вод та формування первинної продукції у водоймах. Внаслідок господарської діяльності людини у водойми можуть надходити біогенні сполуки у надмірних концентраціях, через що утворюються надлишкова первинна продукція, яка супроводжується появою цілого комплексу негативних порушень в екосистемі, що знаходить своє відображення на видовій структурі та чисельності риб 3 . Здебільшого головні сполуки азоту, які знаходяться у воді, - це йони $\mathrm{NH}^{4+}, \mathrm{NO}_{2}^{-}$i $\mathrm{NO}_{3}^{-}$. У разі надлишкового вмісту цих йонів у природних водоймах може спостерігатись порушення рівня евтрофування водойм. Зазвичай їхній негативний влив в основному проявляється в гемолітичній дії ${ }^{14}$. Це відповідно позначається на загальному фізіологічному стані організму ${ }^{15}$. Варто зазначити, що концентрація неорганічних сполук азоту у воді постійно змінюється незалежно від років і сезонності, що може відображатись на фізіологічному стані водних тварин. Крім того, у водоймі встановлено зростання всіх форм азоту: нітритів, нітратів і амонію, що перевищувало референтні значення. В умовному контролі концентрація неорганічного азоту змінювалась не суттєво, що свідчило про їх стабільний фоновий рівень, який не чинив істотного впливу на процеси життєдіяльності місцевих представників іхтіофауни. Свідченням цього були кількісні відмінності у видовому складі населення іхтіофауни двох водойм.

3 огляду на викладену вище інформацію варто зазначити, що зміна вмісту сполук неорганічного азоту у воді однієї із водойм дендропарку

Таблиця 1 - Концентрація сполук азоту у водоймах дендропарку «Олександрія»

\begin{tabular}{|c|c|c|c|c|}
\hline \multirow{2}{*}{ Сполуки азоту } & \multicolumn{2}{|c|}{$2000-2016$ рр. } & \multicolumn{2}{c|}{$2018 \mathrm{p.}$} \\
\cline { 2 - 5 } & $\begin{array}{c}\text { Ставок № 1 } \\
\text { (умовний контроль) }\end{array}$ & $\begin{array}{c}\text { Ставок № 2 } \\
\text { (дослід) }\end{array}$ & $\begin{array}{c}\text { Ставок № 1 } \\
\text { (умовний контроль) }\end{array}$ & $\begin{array}{c}\text { Ставок № 2 } \\
\text { (дослід) }\end{array}$ \\
\hline $\mathrm{NH}_{4}^{+}-\mathrm{N}, \mathrm{мг} /$ дм $^{3}$ & $0,050-0,280$ & $35,09-286,28$ & $0,100-0,276$ & $10,28-65,12$ \\
\hline $\mathrm{NO}_{2}^{-}-\mathrm{N}, \mathrm{мг} /$ дм $^{3}$ & $0,015-0,059$ & $0,32-4,86$ & $0,006-0,059$ & $2,43-4,03$ \\
\hline $\mathrm{NO}_{3}^{-}-\mathrm{N}, \mathrm{M \Gamma} /$ дм$^{3}$ & $0,180-0,340$ & $17,35-100,35$ & $0,08-0,190$ & $110,16-185,20$ \\
\hline
\end{tabular}

Таблиця 2 - Розмірно-масові характеристики риб зі ставків дендропарку «Олександрія»

\begin{tabular}{|c|c|c|}
\hline Показник & $\begin{array}{c}\text { Умовний контроль (водойма № 1), } \\
\mathrm{M} \pm \mathrm{m}, \mathrm{n}=15\end{array}$ & $\begin{array}{c}\text { Забруднена водойма № 2, } \\
\mathrm{M} \pm \mathrm{m}, \mathrm{n}=20\end{array}$ \\
\hline Вік риб, & 3 & 3 \\
\hline Маса риби, г & $77,9 \pm 3,4$ & $24,5 \pm 3,1$ \\
\hline Довжина риби, см & $16,0 \pm 0,9$ & $12,4 \pm 0,5$ \\
\hline Коефіціснт вгодованості за Кларк & $1,7 \pm 0,7$ & $1,3 \pm 0,3$ \\
\hline
\end{tabular}




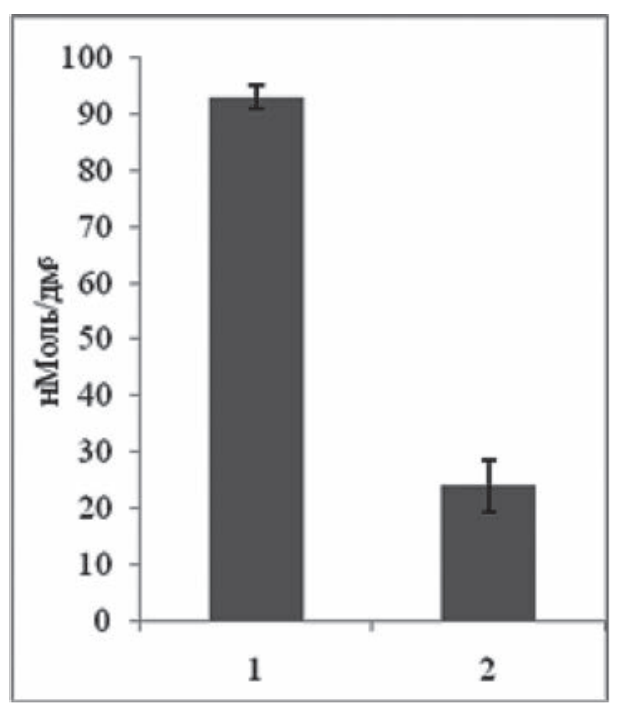

Рис. 1. Рівень Т4 у плазмі крові карася китайського у разі забруднення водойм сполуками неорганічного азоту, 1 - чиста водойма, 2 - забруднена водойма, $\mathrm{M} \pm \mathrm{m}, \mathrm{n}=6$

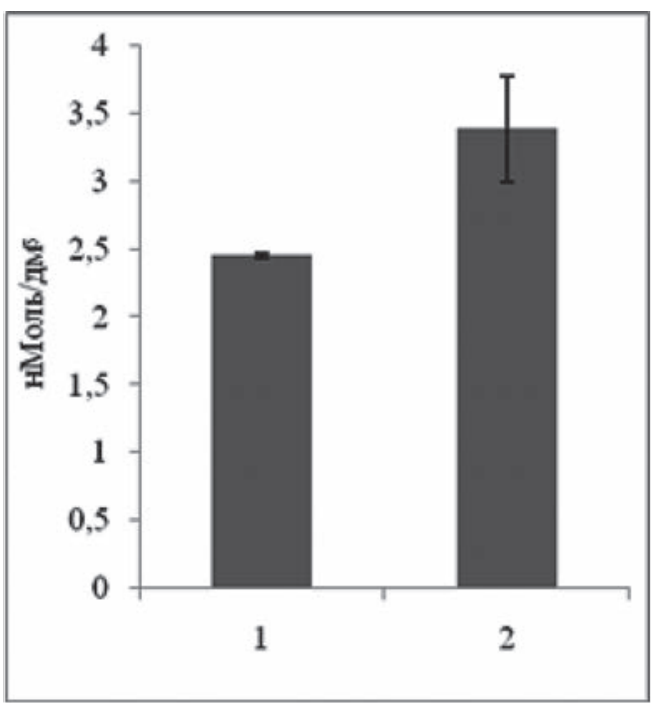

Рис. 2. Рівень Т3 у плазмі крові карася китайського у разі забруднення водойм сполуками неорганічного азоту, 1 - чиста водойма, 2 - забруднена водойма, $\mathrm{M} \pm \mathrm{m}, \mathrm{n}=6$

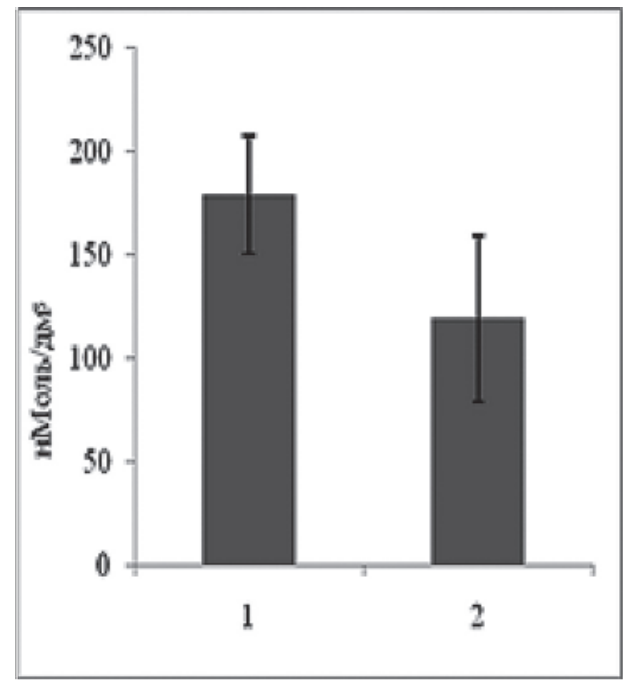

Рис. 3. Рівень кортизолу у плазмі крові карася китайського у разі забруднення водойм сполуками неорганічного азоту, 1 - чиста водойма, 2 - забруднена водойма, $\mathrm{M} \pm \mathrm{m}, \mathrm{n}=6$

«Олександрія» може чинити істотний вплив на особливості функціонування органів та тканин, процеси життєздатності, росту, розвитку та можуть істотно змінювати гормональний фон риб, що там існують. Оскільки нейрогуморальна система однією із перших запускає адаптивні процеси для запобігання локальним наслідкам в угрупованнях дослідних риб. Досліджувані особини карася китайського не є винятком, що відобразилось на його фізіологічному стані та проце- сах росту. Саме у регуляцію цих процесів активно залучені тиреоїдні гормони, зокрема тироксин (T4) та трийодтиронін (Т3) ${ }^{16-17}$. За свідченнями (В.С. Петер) ${ }^{18}$ рівень цих гормонів знижується за дії різноманітних стресорів на риб. У риб, що перебувають у водоймах дендропарку «Олександрія», за тривалого азотного навантаження істотно вищий вміст Т3. Отримані результати могли стати наслідком вимушеного посилення енергетичних процесів, які необхідні для протидії агресивному 
середовищу, у якому перебували досліджувані угруповання карася. Тому зміна вмісту гормонів, можливо, сприяла істотним змінам показників росту. На користь цього свідчили дані лінійномасових показників досліджуваних риб, зокрема у разі перебування у екстремальних умовах. Це своєю чергою вплинуло на посилення адаптивно-компенсаторних процесів у органах і тканинах. Як правило, зміна лінійно-масових характеристик пов'язана із пластичним обміном, що зумовлено характером накопичення енергомістких сполук, зокрема ліпідів та білків, які сприяють накопиченню маси (за рахунок ліпідів) та лінійного росту (за рахунок білків). Ці процеси за нормальних умов існування притаманні для літнього періоду, зокрема липня-серпня. За дії несприятливих факторів ці показники можуть змінюватися, насамперед порушується пластичний обмін, а енергетичний обмін при цьому може навіть зростати. Це знайшло своє відображення у показниках вмісту білків у м'язах та ліпідів у печінці, що були нижчі у забрудненій сполуками азоту водоймі ${ }^{11}$. Це є своєрідним наслідком існування угруповань карася за несприятливих екологічних умов. Зазвичай це певний вихід зі скрутного становища, оскільки риби живуть і розмножуються в умовах «екологічного дискомфорту». 3 огляду на те, що за певних обставин сполуки амонію здатні переходити 3 однієї форми в іншу, через що у гідробіонтів цей процес може викликати незворотні зміни у фізіологічному стані ${ }^{15}$.

Відомо, що Т3 і Т4 беруть участь у процесах, які спрямовані на подолання явищ гострого та хронічного стресу. Зазначені гормони відіграють важливу роль у регуляції обміну речовин: стимуляції окиснювальних процесів та активізації чи послабленні синтезу ліпідів, що виконують захисну роль організму у разі надходження до тканин речовин токсичної природи ${ }^{18-19}$. Під впливом амонійного азоту різної тривалості карась реагував зменшенням вмісту глюкози у крові за вищого вмісту глікогену в органах і тканинах відносно контролю $^{11}$. Це також могло стати наслідком посилення загального обміну через накопичення легкодоступної енергомісткої сполуки у тканинах печінки для подальшого використання за нагальної необхідності. Передусім це важливо для риб, які існують тривалий час у разі дії несприятливого токсичного чинника. Вочевидь, відбувається підвищена потреба у енергоресурсах, які необхідні у разі надходження токсичних речовин в організм риб, зокрема за надмірного азотного навантаження. Зазначені процеси можна розглядати як своєрідну адаптивну стратегію цього виду, що виробилась протягом тривалого процесу пристосування (протягом 20 років). Наслідком таких пристосувань, зокрема й зміни вмісту тире- оїдних гормонів, є підвищення його резистентних можливостей та формування стійкого угруповання, здатного існувати у нетипових умовах, які критично діють на інші види риб. На противагу нашим дослідженням у водоймах Києва у карася рівень гормонів Т3 і Т4 знижувався залежно від токсичного забруднення ${ }^{20}$.

Відомо, Т4 активно перетворюється на трийодтиронін та використовується для підтримки енергетичного обміну на високому рівні, що пов'язано з особливостями конкретного виду та чинників впливу. Проте найактивнішою формою тиреоїдних гормонів є Т3, йому властива більша спорідненість до відповідних рецепторів у тканинах, ніж Т4. Звичайно, коливання вмісту неорганічного азоту протягом різних сезонів та років призводить до повних змін у енергетичному обміні, що відображається на зміні вмісту двох гормонів. Проте за період послаблення токсичного навантаження відбувається накопичення енергомістких сполук, що, відповідно, дає можливість бути більш підготовленими до дії агресивного середовища у подальшому. Тому зміни рівня гормонів у риб із досліджуваних водойм пов'язані із пристосувальними особливостями досліджуваного виду, які спрямовані на забезпечення адекватної відповіді організму за умов хронічного довготривалого стресу у разі існування у відносно нестабільному середовищі.

Внутрішньовидові відмінності у рівні гормонів у карася китайського пов'язані перш за все із характером дії токсичних сполук різного хімічного походження, а також адаптивними можливостями досліджуваного виду долати негативний вплив токсичного забруднення.

Також було розглянуто зміни вмісту кортизолу. Відомо, що за дії деяких токсикантів, зокрема сполук фенолу та свинцю, рівень кортизолу істотно знижується, що пов'язано із пригніченням інтерренальної залози ${ }^{21}$. Кортизол виконує функції відновлення гомеостазу в післястресовий період ${ }^{22-23}$ та має енергозаощаджуюче значення ${ }^{7}$. У попередніх дослідженнях, проведених на коропових видах риб, було виявлено міжвидові відмінності у нормі реакції, що відображалось у змінах гормонів тироксину, трийодтироніну та кортизолу. Тому для попередження повторних ситуацій на інших водоймах м. Києва та України загалом необхідно проводити періодичний моніторинг змін гормонального фону риб (з різних екологічних ніш та шарів водойми), які існують у водних об'єктах, що перебувають під прямим та/або опосередкованим впливом людини. Такі заходи необхідні для збереження оптимального екологічного стану природних та штучних водойм. Оскільки зміни вмісту кортизолу в сироватці крові $є$ першочерговою реакцією організму на стресори, зокрема 
у разі дії токсичних сполук, тому зміни рівня цього гормону застосовують для оцінки ступеня забруднення водойми та прогнозування його наслідків для природних угруповань риб ${ }^{16}$. Нижчий вміст кортизолу може також свідчити про певні пристосувальні реакції карася в умовах тривалого амонійного забруднення та відсутність гострого стресу (на момент проведення досліджень).

Результати наших досліджень узгоджуються iз даними, отриманими стосовно вмісту кортизолу у плазмі крові карася китайського у разі існування протягом тривалого часу у водоймах з інтенсивним забрудненням нафтопродуктами та важкими металами. 3 огляду на тривалість впливу на угруповання карася китайського сполук амонію відбувались пристосувальні зміни у фізіологічному стані, передусім вмісту гормонів Т3, Т4 та кортизолу, що несе в собі адаптивний характер. Крім того, зміна цих показників адекватно відображає умови існування, де тривалий час перебуває угруповання зазначеного виду. У зв'язку з активізацією обмінних процесів, пов'язаних із детоксикацією і виведенням надлишкового амонію, істотно змінюється біохімічний склад крові карася ${ }^{24}$. Передусім отримані результати дозволяють припустити істотні перебудови у процесах енергозабезпечення риб, що відобразилось на вмісті енергомістких сполук та лінійно-масових характеристиках досліджуваних особин карася китайського.

Також отримані нами результати стосовно зміни вмісту кортизолу, трийодтироніну та тироксину продовжують цикл робіт, присвячених існуванню риб у нетипових для них екологічних умовах існування, спричинених надмірним впливом забруднення.

Разом із тим за роки існування у антропогеннозабруднених водоймах (на прикладі ставів ден- дропарку «Олександрія») у риб відбулись перелаштування обмінних процесів відповідно до наявних екологічних умов навколишнього середовища, що носять адаптивний характер. Саме тому дослідні види риб продовжують існувати у водоймах із різним токсичним забрудненням та підтримувати чисельність своїх угруповань.

\section{Висновки}

За результатами досліджень було встановлено зміни вмісту тиреоїдних гормонів у разі тривалого існування угруповань карася китайського за амонійного навантаження.

$\mathrm{У}$ карася, який тривалий час перебував уводоймі, щозабруднена сполуками неорганічного азоту, рівень тироксину був менший (у 3,87 раза), а трийодтиронін вищий (у 1,38 раза). Це підтверджує їх участь у адаптивно-компенсаторних реакціях на токсичний вплив йонів амонію.

Було встановлено пряму кореляційну залежність між зміною трийодтироніну у плазмі крові i концентраціями йонів амонію $(\mathrm{r}=0,847)$. Також показано обернену кореляційну залежність між змінами тироксину у плазмі i концентраціями йонів амонію $(\mathrm{r}=-0,773)$.

Отримані результати свідчать про можливість здійснювати контроль за фізіологічним станом угруповань риб у разі надмірного впливу забруднення води за зміною вмісту гормонів, зокрема кортизолу, тироксину та трийодтироніну.

Вміст гормонів у плазмі крові риб може розкривати деякі аспекти адаптивних процесів, пов'язаних з існуванням у надмірно забруднених водоймах. Це дає можливості для проведення подальших досліджень із залученням додаткових показників для більш глибинного розуміння особливостей видової стратегії досліджуваного виду виживати там, де інші вимирають.

\section{Література}

(1) Tilak, K.S.; Veeraiah, K.; \& Ryu, M.P. Effects of Ammonia, Nitrite and Nitrate on Hemoglobin Content and Oxygen Consumption of Freshwater Fish, Cyprinus carpio (Linnaeus). Journal of environmental biology. 2007, 28 (1), 45-47.

(2) Metwally, M.A.A.; \& Wafeek, M. Effect of Ammonia Toxicity on Carbohydrate Metabolism in Nile Tilapia (Oreochromise niloticus). World journal of fish and marine sciences. 2014, 6 (3), 252-261. http://doi: 10.5829/idosi.wjfms.2014.06.03.83245.

(3) Camargo, J.A., Alonso, A. (2006). Ecological and Toxicological Effects of Inorganic Nitrogen Pollution in Aquatic Ecosystems: A Global Assessment. Environ. Int. 32 (6): 831-8490. DOI: 10.1016/j. envint.2006.05.002.

(4) Svobodova, Z.; Machhova, J.; Kroupova, H.; Smutna, M.; \& Groch, L. Ammonia Autointoxication of Common Carp, Case Studies. Aquaculture International. 2007, 15, 227-286. http://doi.org/10.1007/ s10499-007-9079-0.

(5) Cardoso, E.L.; Chiarini-Garcia, H.; Ferreira, R.M.A.; Poli, C.R. Morphological Changes in the Gills of Lophiosilurus alexandri Exposed to Un-ionized Ammonia. Journal of Fish Biology. 1996, 49 (5), 778-787. DOI: 10.1006/jfbi.1996.0210.

(6) de La Torre, F.R.; Ferrari, L.; A. Salibián, A. Biomarkers of a Native Fish Species (Cnesterodon decemmaculatus) Application to the Water Toxicity Assessment of a peri-Urbanpolluted River of Argentina. Chemosphere 2005, 59 (4), 577-583. DOI: 10.1016/j.chemosphere.2004.12.039 
(7) Sinha, A.K.; Liew, H.J.; Kumar, M. et al. Combined Effects of High Environmental Ammonia, Starvation and Exercise on Hormonal and Ion-regulatory Response in Goldfish (Carassius auratus L.). Aquatic Toxicology 2012,114-115, 153-164. DOI.org/10.1016/J.aquatox.2015.01.005.

(8) Peter, M.C. The Role of Thyroid Hormones in Stress Response of Fish. General Comparative Endocrinology. 2011, 172 (2), 198-210. http://doi.org/10.1016/j.ygcen.2011.02.023.

(9) Oleynik, G.N.; Starosyla, G.N. (2005). Microbiological Characteristics of Water Bodies Subjected to Intensive Anthropic Load. Hydrob. Journal. 2005, 41 (60), 66-77. DOI: 10.1615/HydrobJ.v41.i6.50.

(10) Romanenko, V.D.; Potrokhov, A.S.; Zin'kovskiy, O.G. Hormonal Mechanism of Energy Supply of the Fish Adaptation to the Inorganic Nitrogen Impact. Hydrobiol. Journal. 2011, 47 (2), 55-62. DOI: 10.1615/HydrobJ.v47.i2.60.

(11) Коваленко, Ю.О.; Примачев, М.Т.; Потрохов, О.С.; Зіньковський, О.Г. Деякі Адаптивні Реакції Карася Сріблястого Carassius auratus gibelio (Bloch) за Надмірного Навантаження Амонійним Азотом. Рибогосподарська наука України 2018, 2 (44), 116-129. DOI: 10.15407/fsu2018.02.116.

(12) Арсан, О.М.; Давидов, О.Я.; Дяченко Т.М. та ін. Методи Гідроекологічних Досліджень Поверхневих Вод. Київ: Логос, 2006. 408.

(13) Резніков, О.Г. Проблеми етики при проведенні експериментів медичних та біологічних досліджень на тваринах України. Перший національний конгрес з біоетики. Тези доповідей. Київ, 2001, 10.

(14) Патика, В.П.; Макаренко, Н.А.; Моклячук, Л.І. та ін. Агроекологічна Оцінка Мінеральних Добрив та Пестицидів: Монографія, Київ: Основа, 2005, 300 с.

(15) Губський, Ю.І. Біологічна хімія: Підручник. Київ-Тернопіль: Укрмедкнига, 2000, 508 с.

(16) Prychepa, M.V.; Potrokhov, A.S. Hormonal Regulation of Adaptive Processes in Fishes to Impact of Abiotic Factors (a Review). Hydrobiological Journal 2016, 52 (3), 86-98. DOI: $10.1615 /$ HydrobJ.v52.i3.80.

(17) Nahed, S.; Gad, S. Effect of environmental pollution by phenol on some physiological parameters of Oreochromis niloticus. Global Veterinaria 2008, 2 (3), 312-319.

(18) Peter, M.C.S.; Elizabeth, K.L.; Vijayamma, J.; \& Peter, V.S. Thyroid Hormone Modifies the Metabolic Response of Air-breathing Perch (Anabas testudineus Bloch) to Nimbecidine Exposure. Journal Endocrinology and Reproduction. 2009, 1, 27-36. http://doi.org/10.18311/jer/2009/2013.

(19) Peter, V.S.; Joshua, E.K.; Wendelaar Bonga, S.E.; \& Peter, M.C. Metabolic and Thyroidal Response in Air-breating Perch (Anabastes tudineus) to Water-borne kerosene. General Comparative Endocrinology. 2007, 152, 198-205.http://doi.org/10.1016/j.ygcen.2007.05.015.

(20) Коваленко, Ю.О.; Шлапак, О.О.; Потрохов, О.С.; Зіньковський, О.Г. Вплив Антропогенного Забруднення Водойм на Фізіолого-біохімічні Показники Риб та Склад їхніх паразитоценозів. Рибогосподарська наука України. 2019, 3 (49), 72-88. DOI: 10.15407/fsu2019.03.072.

(21) (21)Varadarajan, H.; Sankar, H.S.; Jose, J.; Philip, B. Sublethal effects of phenolic compounds on biochemical, histological and ionoregulatory parameters in a tropical teleost fish Oreochromis mossambicus (Peters). International Journal of Scientific and Research Publications 2014. 4 (3), 1-12.

(22) Monteiro, S.M.; Mancera, J.M.; Fernandes, A.F.; Sousa, M. Copper Induced Alterations of Biochemical Parameters in the Gill and Plasma of Oreochromis niloticus. Comp Biochem Physiol. 2005, 141 C, 375-383. DOI: 10.1016/j.cbpc.2005.08.002. Epub 2005 Sep 26.

(23) Zeitoun, M.M.; EL-Azrak, K.D.E.M.; Zaki, M.A.; Bahig, R. Nemat-Allah, B.R.; \& Mehana, E.S.E. Effects of Ammonia Toxicity on Growth Performance, Cortisol, Glucose and Hematological Response of Nile Tilapia (Oreochromis niloticus). Aceb Journal of Animal Sciense. 2016, 1(1), 21-28. http://doi.org/10.13170/ajas.1.1.4077.

(24) Худіяш, Ю.М.; Причепа, М.В.; Потрохов, О.С.; Зіньковський, О.Г. Особливості Впливу Амонійного Азоту на Фізіологічні Показники Карася Сріблястого Carrasius auratus (Linnaeus, 1758). Mатеріали ХІІ Міжнародної іхтіологічної науково-практичної конференції Сучасні проблеми теоретичної та практичної іхтіологї̈. 26-28 вересня 2019 року, м. Дніпро. 206-209. 